\title{
Comparison of the state of Lithium-Sulphur and Lithium-ion batteries applied to electromobility
}

\author{
G. Benveniste ${ }^{(1)}$, H. Rallo ${ }^{(2,3)}$, L. Canals Casals ${ }^{(1)}$, A. Merino ${ }^{(2)}$, B. Amante ${ }^{(3)}$ \\ ${ }^{(1)}$ Institut de Recerca en Energia de Catalunya - IREC \\ Jardins dones de negre, 1-08930 - Sant Adrià de Besòs (Spain) \\ gbenveniste@irec.cat \\ (2) Centro Técnico SEAT S.A. - Electrical development EE-S5 - PhD program \\ Autovía A2-km 585 - 08760 - Martorell (Spain) \\ (3) Universitat Politècnica de Catalunya - Barcelona TECH \\ Carrer Colom, 11 - 08222 - Terrassa (Spain)
}

\author{
Keywords: \\ Electric Vehicle \\ Li-S battery \\ Specific Energy \\ Modelling \\ Electric Equivalent Circuit \\ Environmental assessment
}

\begin{abstract}
:
The market share in electric vehicles (EV) is increasing. This trend is likely to continue due to the increased interest in reducing $\mathrm{CO}_{2}$ emissions. The electric vehicle market evolution depends principally on the evolution of batteries capacity. As a consequence, automobile manufacturers focus their efforts on launching in the market EVs capable to compete with internal combustion engine vehicles (ICEV) in both performance and economic aspects. Although EVs are suitable for the day-to-day needs of the typical urban driver, their range is still lower than ICEV, because batteries are not able to store and supply enough energy to the vehicle and provide the same autonomy as ICEV.
\end{abstract}

EV use mostly Lithium-ion (Li-ion) batteries but this technology is reaching its theoretical limit (200-250 Wh/kg). Although the research to improve Li-ion batteries is very active, other researches began to investigate alternative electrochemical energy storage systems with higher energy density. At present, the most promising technology is the Lithium-Sulphur (Li-S) battery.

This paper presents a review of the state of art of Li-Sulphur battery on EVs compared to Li-ion ones, considering technical, modelling, environmental and economic aspects with the aim of depicting the challenges this technology has to overcome to substitute Li-ion in the near future. This study shows how the main drawbacks for Li-S concern are durability, self-discharge and battery modelling. However, from an environmental and economic point of view, Li-S technology presents many advantages over Li-ion. 


\section{Introduction}

Late in the 19th century the first Electric Vehicle (EV) was build powered by electrochemical batteries. Nevertheless car manufacturers dedicated all their efforts in favour of the Internal Combustion Engine Vehicle (ICEV) due to it being more efficient and powerful technology at that moment (Schiffer, 2016).

It was not until the end of the twentieth century when world population and their governments in consequence, became aware of the side effects of ICEVs and began to worry about their environment impact, which are extremely polluting and produce large amounts of greenhouse gas (GHG) emissions, approximately $27 \%$ of world's GHG emissions are produced by ground transportation sector (Deng et al., 2017). The International Organization of Motor Vehicle Manufacturers (OICA) declared in 2014 that there were more than 1.200 million cars in the world and forecasted 2000 million additional vehicles in 2035, which represent a $60 \%$ increase. Thus, the environmental impact would increase accordingly if no measures are taken. To counteract this phenomenon the European Parliament (European Commission - Climate Action) passed a law requiring that all vehicles manufactured after 2020 should emit less than $95 \mathrm{~g} / \mathrm{km}$ of $\mathrm{CO}_{2}$ to the atmosphere and $68-78 \mathrm{~g} / \mathrm{km}$ in 2025 (EP, 2011). To comply with the requirements of this new law, car manufacturers are developing alternative less polluting vehicles (Hackbarth and Madlener, 2013), putting most of their efforts upon EVs.

EVs technology development and its deployment goes hand by hand with the advances in portable energy storage devices: the battery. This is, in fact, the most important component of EVs as it determines the car performance. With the introduction of Lithium-lon (Li-ion) batteries on EVs, these have increased their driving range substantially and provide to common urban drivers almost all their day-to-day needs (Fotouhi et al., 2016b). Li-ion battery technology has evolved considerably since the first commercial unit for portable applications was produced in 1990 (Zakeri and Syri, 2015). However, this chemistry has not yet been able to replace ICEV due to their range limitations and higher prices (Fang and Peng, 2015). EVs have an average driving distance of $250 \mathrm{Km}$ (Fotouhi et al., 2017b)(Bonges and Lusk, 2016), while conventional ICEVs may achieve $1000 \mathrm{Km}$.

Research to improve Li-ion batteries is very active, but some authors point out that Li-ion batteries are reaching their practical specific energy limit (200-250 Wh/kg) (Barchasz et al., 2012), which is not good enough to meet the market requirements (Bresser et al., 2013). In order to accomplish a target range of $500 \mathrm{Km}$, and a consumption of $15 \mathrm{kWh} / 100 \mathrm{~km}$, estimations point that batteries should reach a practical specific energy of $550 \mathrm{Wh} / \mathrm{kg}$ (Climate and Project, 2006).

For this reason, both industries and research institutions are showing interest in the study of alternative electrochemical energy storage systems with higher energy density. At present, one of the most promising technologies is Lithium-Sulphur (Li-S) not only for their higher theoretical energy density (about $2600 \mathrm{Wh} / \mathrm{kg}$ ) but also for the relatively inexpensive and nonpoisonous materials used in their manufacture that are expected to reduce the overall battery price and environmental impact (Peng et al., 2017). To reinforce this interest, over the past years, the European Commission $(\mathrm{EC})$ has been founding research projects related to the development of Li-S cells technology. 
In 2016 ended the first of these projects, EUROLIS (Advanced European Lithium Sulphur cells for automotive application) (EUROLIS, n.d.). The main outcome of this project was the development on carbon matrices and their synthesis and electrolyte to obtain effective electrode separation in Li-S batteries that would prolong the Li-S battery cycling lifetime. One year later, in 2017, also finished ECLIPSE (European Consortium for Lithium-Sulphur Power for Space Environments) (ECLIPSE, n.d.). The aim of this project was to demonstrate the feasibility of Li-S cells on space applications.

As a continuation of EUROLIS project, HELIS (High Energy Lithium Sulphur Cells and Batteries) project is now on-going (HELIS, n.d.). HELIS aims at preparing different sets of Li-S prototype cells capable to reach $500 \mathrm{Wh} / \mathrm{kg}$ of energy capacity, $1000 \mathrm{~W} / \mathrm{kg}$ power capacity and a cycle life longer than 1000 cycles. In parallel to HELIS, ALISE (Advanced Lithium Sulphur Battery for Electric Vehicles) (ALISE, n.d.) project aims at achieving same energy density cells ensuring safety and adequate cyclability of the battery at reduced costs.

Li-S batteries have emerged as a promising battery technology due to the positive consequences of replacing metals in the cathode of typical Li-ion batteries by Sulphur. For one side, Sulphur is one of the most abundant elements on earth and is also a valuable by-product to be recovered in desulphurization processes by oil and gas industries (Eow, 2002). Secondary Sulphur is an electrochemically active material that can accept up to two electrons per atom at $2,1 \mathrm{~V}$ versus $\mathrm{Li} / \mathrm{Li}+$. Moreover, Sulphur cathode materials have a very high theoretical capacity of $1675 \mathrm{mAh} / \mathrm{g}$. Consequently, Li-S batteries have a theoretical energy density of around 2600 $\mathrm{Wh} / \mathrm{kg}$, an entire magnitude of order higher than typical Li-ion batteries (Manthiram et al., 2013). Figure 1 shows the energy density of different battery chemistries and how current Li-S batteries achieve higher densities compared to other types.

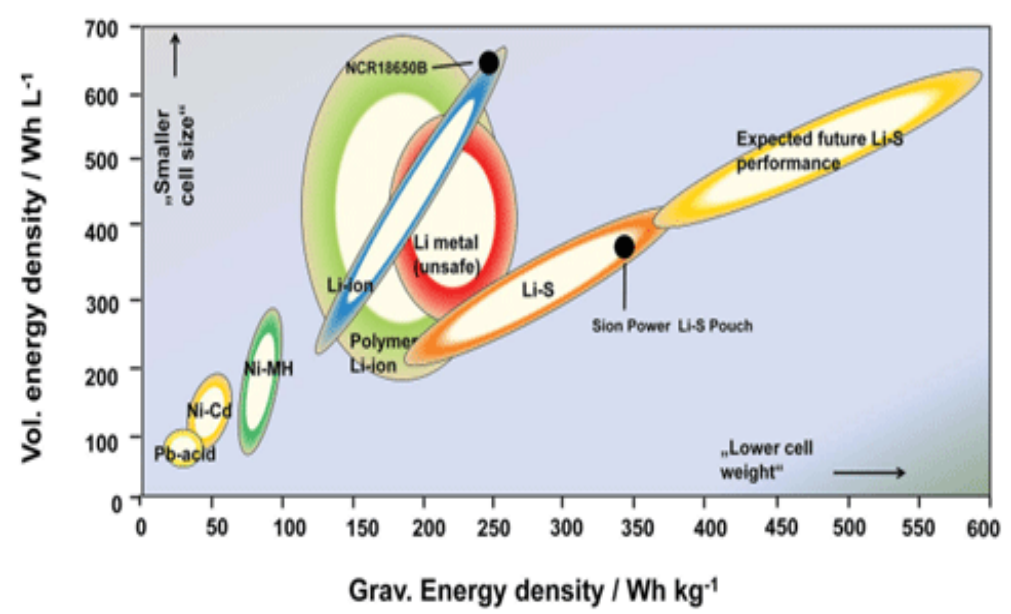

Figure 1. Energy densities of different batteries chemistry Source ((Hagen et al., 2015)

Nevertheless, Li-S technology for batteries presents several disadvantages and technical challenges that need to be solved in order to overtake Li-ion batteries predominance in the market. These disadvantages, such as self-discharge, short cycle life and too-low coulombic efficiency (Peled et al., 2017a), are now focusing the Li-S technology research and will be further explained in section 3 of this study. 
This paper aims at analysing the current development status of Li-S cells and batteries through an extensive literature inspection. The paper also indicates the main critical points related to Li-S technology compared to Li-ion and how research strives to overcome them and make this promising technology a reality in a mid/short-term.

\section{Experimental}

The literature research was conducted using two main databases, Scopus and Web of Science using the search terms: "Li-S", "battery" and the Boolean "AND" that found 2.885 articles. Filtering by engineering topic the results drop down to 1.511. Although, as it can be observed in Figure 2 (left) the topic with more results is chemical with 2.297. This search was repeated using "Li-Sulphur" AND "batteries" with the different possible combinations; no new articles were identified.
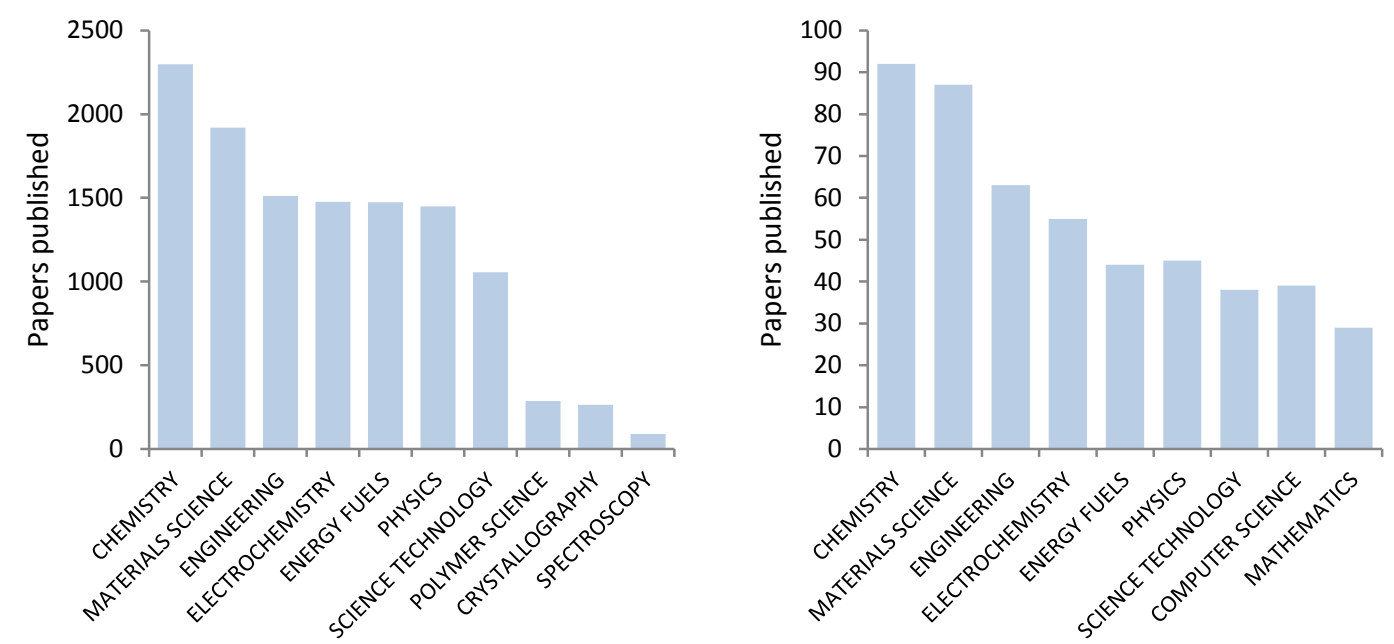

Figure 2: Li-S battery papers published filtered by topic (Left). Li-S battery modelling papers published filtered by topic (right)

An advanced search using the terms "battery", "Li-S" AND "model\$”" showed a total of 373 articles Figure 2 (right). Notice that the total journals published between 2014 and 2018 is 170 Figure 3 (left) which represents $46 \%$ showing that the research in this field is very recent (Pope and Aksay, 2015). Separating by engineering topic the results are 63 articles (17\%). No less remarkable is that filtering by chemistry and materials, results rise up to $47 \%$ ( 179 articles), showing that most of research is still working on the basics of the technology rather than in possible applications. Observing Figure 3 (right) it is also interesting to remark that China, USA, South Korea and Germany are the countries with more publications with $59 \%, 18 \%, 6 \%$ and $4 \%$ respectively, coinciding with the countries where EV's development is more advanced and also, where more electric cars are sold (IEA, 2017). 


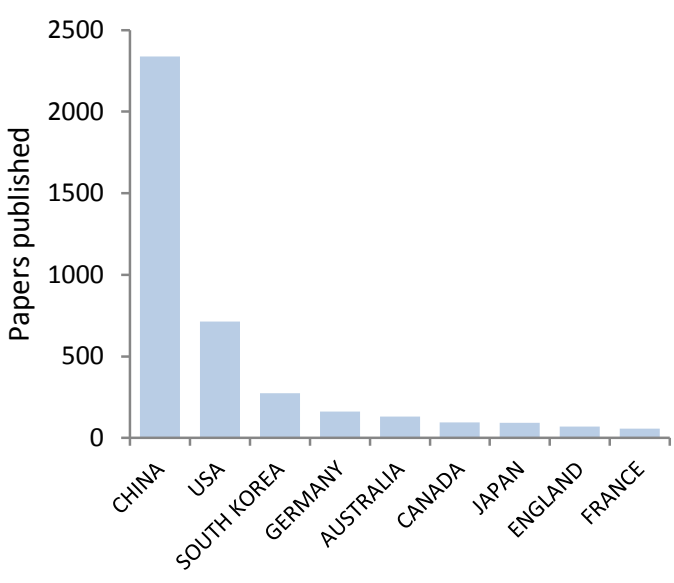

Figure 3: Evolution of Li-S publications by year (Left) and distribution per country (Right)

This bibliometric analysis has been useful to identify the current state and performance of Li-S batteries and to compare them against Li-ion. Moreover it has been used to determine the most appropriate method for battery modelling according to each technology and to compare the environmental impact of Li-S against most relevant Li-ion battery technologies.

To perform the economic analysis, this study has taken the prices of the principal elements used in most performant commercial Li-ion batteries comparing them against Sulphur. Prices were collected for the last seventeen years from the USGS National Minerals Information Center databases.

\section{Results and Discussion}

This section is divided in four subsections. The first one analyses technical aspects of the Li-S batteries based on their the physical and chemical characteristics compared to Li-ion, the second part focuses on battery models in relation to EV applications and the third and fourth subsections show the results obtained from the review of the environmental and economic aspects of Li-S cells and batteries for EV applications respectively.

\subsection{Chemical and physical characteristics}

Li-S technology is not just another modification on the Li-ion chemistries; the replacement of metals by Sulphur in the cathode makes them perform in a different manner. Thus, many concepts learned from Li-ion cannot be implemented on Li-S batteries due to the different chain of chemical reactions that take place.

Li-ion cells have just one chemical reaction: Lithium ions insert into the molecular structure of the carbon electrode (intercalation) all through the discharge process. On the contrary, in Li-S cells, Sulphur reacts with Lithium ions when reduced from elemental state $S_{8}$, via the intermediates $\mathrm{Li}_{2} \mathrm{~S}_{8}, \mathrm{Li}_{2} \mathrm{~S}_{4}, \mathrm{Li}_{2} \mathrm{~S}_{2}$, to Lithium sulphide $\mathrm{Li}_{2} \mathrm{~S}$ depending on the State of Charge (SOC) (Fotouhi et al., 2016b), (Propp et al., 2016). 
Nowadays, Li-S batteries practical energy density is considered to be between 200 and 500 $\mathrm{Wh} / \mathrm{kg}$ (Table 1 and Figure 4) which lower limit is within the current values obtained for high performance packs.

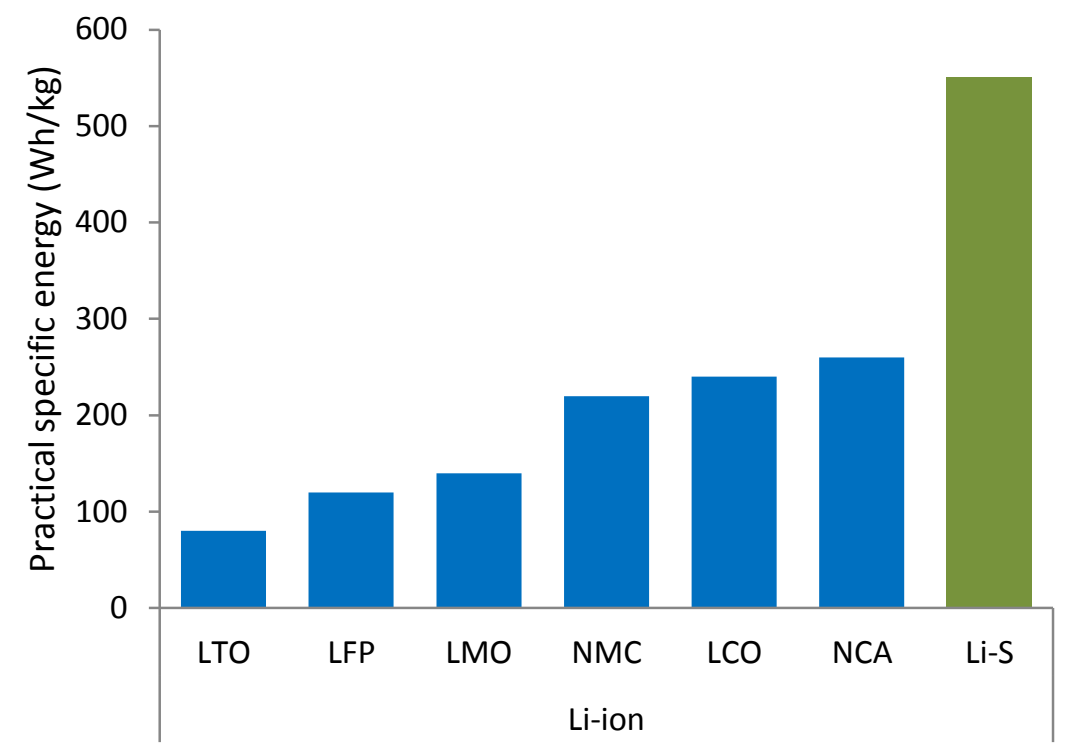

Figure 4 Comparison of the Practical Specific Energy (Wh/kg) of Li-ion and Li-S.

It seems that all chemistries based on Li-ion have a correlation between the theoretical energy density and the accessible practical capacity of three times less (Bruce et al., 2011), (Pope and Aksay, 2015), (Wadia et al., 2011), (Thackeray et al., 2012). On the other hand, the theoretical capacity of Li-S battery is $1675 \mathrm{mAh} / \mathrm{g}$ making its theoretical gravimetric energy density 2600 Wh/kg (Kang et al., 2016), (Abruña, 2014), so the actual correlation for Li-S between theoretical and practical energy density is around ten times less, as shown in Table 1Error! Reference source not found., being at the very beginning of the learning curve and having a strong potential to improve current battery performances. Assuming that the relation between theoretical and maximum practical energy density hardly ever exceeded the 1/3 (Wadia et al., 2011) it can be confirmed that Li-ion batteries are effectively reaching their practical energy density limit while Li-S, with a current state of $200-500 \mathrm{Wh} / \mathrm{kg}$ have still a large margin to improve their practical capacity, concluding that the practical specific energy of Li-S could reach in a near future almost $900 \mathrm{Wh} / \mathrm{kg}$, which is more than four times the actual value of $\mathrm{Li}$ ion batteries.

Additionally, apart from the better capacity Li-S cells have, these are able to work throughout all SOC windows from $0 \%$ to $100 \%$. This is a significant opportunity to exploit all the capacity, instead, Li-ion cells have to leave a margin of safety reducing the window work by approximately $20 \%$ of SOC (Fotouhi et al., 2017a). 
Comparison of characteristics of Lithium-ion cells and Lithium/Sulphur cells

(Song et al., 2013)(Manthiram et al., 2013)(Amarakoon et al., 2013)(Isidor. Buchmann, 2016)(Väyrynen and Salminen, 2012) (Yan et al., 2014)(Fotouhi et al., 2017a)

\begin{tabular}{|c|c|c|c|c|c|}
\hline & \multicolumn{4}{|c|}{ Li-ion } & \multirow{2}{*}{ Li-S } \\
\hline & NMC & NCA & LCO & LFP & \\
\hline Cell voltage (V) & 3,70 & 3,60 & 3,65 & 3,20 & 2,15 \\
\hline Theoretical specific energy (Wh/kg) & $400-600$ & $400-600$ & $400-600$ & $300-400$ & 2600 \\
\hline Practical specific energy (Wh/kg) & 220 & 260 & 240 & 120 & $200-550$ \\
\hline Practical/Theoretical correlation & $\approx 1 / 2,5$ & $\approx 1 / 2,5$ & $\approx 1 / 2,5$ & $\approx 1 / 2$ & $\approx 1 / 10$ \\
\hline Power density (W/L) & 320 & 270 & 450 & 200 & $100-200$ \\
\hline Cycle life (cycles) & $1000-2000$ & 500 & $\approx 700$ & $1000-2000$ & $\approx 50$ \\
\hline Self-Discharge Rate (month) & $1 \%$ & $1 \%$ & $1 \%$ & $1 \%$ & $8-15 \%$ \\
\hline Thermal runaway $(\stackrel{\circ}{ } \mathrm{C})$ & 210 & 150 & 150 & 270 & 120 \\
\hline Work window (SOC) & $15-95 \%$ & $15-95 \%$ & $15-95 \%$ & $15-95 \%$ & $0-100 \%$ \\
\hline Memory effect & \multicolumn{4}{|c|}{ No } & Yes \\
\hline Properties & $\begin{array}{l}\text { High voltage, } \\
\text { good specific } \\
\text { capacity, high } \\
\text { safety risk, } \\
\text { good lifetime }\end{array}$ & $\begin{array}{l}\text { High energy, } \\
\text { high density, } \\
\text { expensive }\end{array}$ & $\begin{array}{l}\text { High safety } \\
\text { risk, good } \\
\text { lifetime }\end{array}$ & $\begin{array}{c}\text { Long } \\
\text { lifetime, high } \\
\text { stability, } \\
\text { basic low } \\
\text { cost }\end{array}$ & $\begin{array}{c}\text { High energy } \\
\text { density, } \\
\text { cheap, low } \\
\text { environment } \\
\text { al impact, } \\
\text { low safety } \\
\text { risk }\end{array}$ \\
\hline Applications - Automotive & EV, HEV, PHEV & $\begin{array}{c}\text { EV, HEV, } \\
\text { PHEV }\end{array}$ & EV, HEV & $\begin{array}{l}\text { EV, HEV, } \\
\text { PHEV }\end{array}$ & EV \\
\hline
\end{tabular}

Table 1: Comparison of the characteristics of Li-ion and Li-S cells and batteries

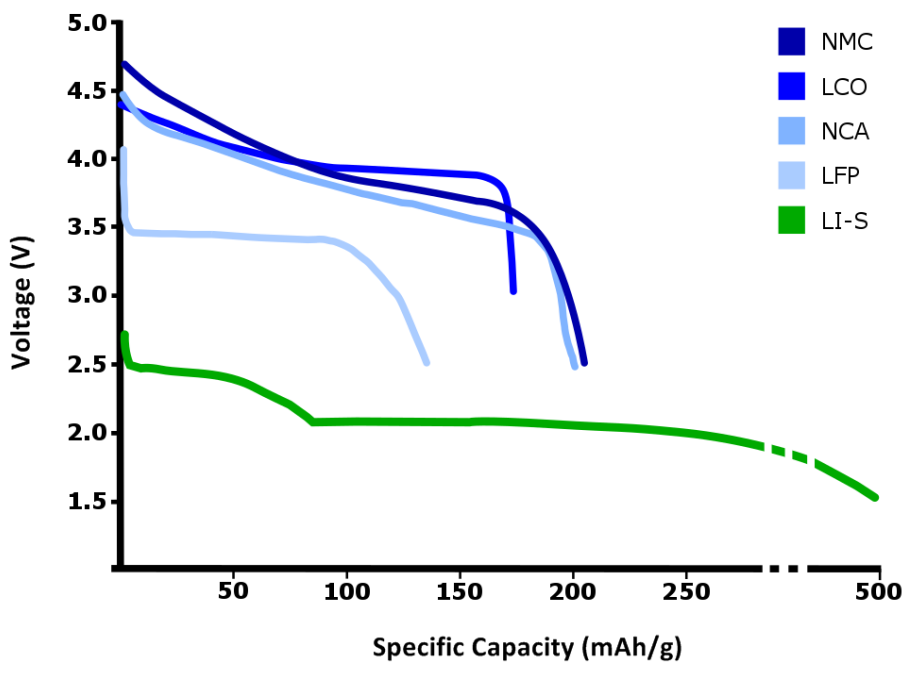

Figure 5: Discharge curves of Li-S and different Li-ion chemistries.

Table 1 and Figure 5 depict that although Li-S technology has a better theoretical specific energy than Li-ion and also a very good margin to improve its practical specific energy, there are also some other factors that are far from overtaking Li-ion chemistry properties.

While in Li-ion batteries, cathode materials range varies from Lithium Cobalt Oxide (LCO), Lithium Manganese Oxide (LMO) or Lithium Nickel Manganese Cobalt Oxide (NMC), among others (Isidor. Buchmann, 2016), elemental Sulphur is the main cathode material in Li-S and this is closely related to its structure and electrochemical properties (Kang et al., 2016), . Li-S batteries, as well as Li-ion batteries, use Lithium on the anode due to its extremely high theoretical specific capacity of $3860 \mathrm{mAh} / \mathrm{g}$ and the lowest negative electrochemical potential of $-3,040 \mathrm{~V}$ (Peng et al., 2017). Although Li-S battery present many advantages that make it a suitable candidate for EVs applications, the low conductivity of sulphur $\left(5 \times 10^{-30} \mathrm{~S} / \mathrm{cm}\right.$ at 25 
${ }^{\circ} \mathrm{C}$ ) (Chen et al., 2014) and the expansion of the cathode upon lithiation and the solubility of Sulphur and of Lithium polysulphides in the electrolytes cause of many effects such as selfdischarge, short cycle life and too-low coulombic efficiency (Peng et al., 2017)(Peled et al., 2017b) affecting negatively the performance of the battery. The expansion of the cathode occurs because the different molar volumes of Lithium sulphide and polysulphides compared to Sulphur ( $80 \%$ greater). Partial dissolution of polysulphides causes anode corrosion and leads to the formation of shorter polysulphide compounds. Short polysulphides, in turn, diffuse and migrate to the cathode where they re-oxidize or react with the solid Sulphur at the cathode to form longer polysulphides, initiating a shuttle mechanism, which leads to low energyconversion efficiency (Peled et al., 2017a). In the case of high-loading Li-S batteries, the shuttle effect will be more serious as the polysulfide crossover is multiplied (Hofmann et al., 2014). In fact, shuttle effect occurs more at low and uniform charging current rates (Hofmann et al., 2014).

In order to mitigate the effect of the low conductivity of Sulphur, some research proposes to downsize the Sulphur to nanosize particles and adding a large amount of carbon. However, this method unfortunately sacrifice the energy density of the Li-S cells due to the fact that high fractions of light carbon materials like porous carbon or carbon nanotube (CNT) lower the volumetric energy density considerably. For instance, if the carbon content achieves around 30 $\%$ of the total cathode weight, the energy density of the cell can decrease c.a. $25 \%$ (Gao and Abruña, 2014). This is a relevant drawback when designing energy storage systems for portable applications such as EVs (Lv et al., 2015).

Furthermore, in order to reduce the effect of the cathode expansion and it has been proposed to assemble a Sulphur battery in a fully-lithiated state by using $\mathrm{Li}_{2} \mathrm{~S}$ as an active cathode material as it enables combining safer, Lithium-metal-free anodes and eliminates expansion and breaking of the cathode on lithiation (Peled et al., 2018).

In parallel, several research studies have been conducted to mitigate the negative effect of the polysulphide shuttle. Much of this work has focused on either the protection of the Lithium anode or on the restriction of the ionic mobility of the polysulphide anions. However, since protection of the Lithium anode causes a slow reaction rate at the anode during the discharge cycle due to passivation of the anode, this leads to a loss of power density in the battery. Gel electrolytes and solid electrolytes have been reported as a means of slowing down the polysulphide shuttle by reducing the ionic mobility of the electrolytes (Barghamadi et al., 2013). Another solution proposed is to use $\mathrm{LiNO}_{3}$ on the anode to promote the formation of a stable passivation film, which is known to significantly suppress the redox shuttle of Lithium polysulphide. $\mathrm{LiNO}_{3}$ is beneficial to Li-S battery only when its irreversible reduction on the cathode is avoided, which can be easily achieved by raising the discharge cut-off voltage (Zhang, 2012)(Diao et al., 2013) (Xiong et al., 2014)(Adams et al., 2017) although the exact nature of the $\mathrm{LiNO}_{3}$ functionality is still unclear (Ebadi et al., 2017).

Besides the chemical properties and inherent trade-offs, Li-S batteries present a unique charge and discharge mechanisms, that at the moment it has not been fully characterised (Peng et al., 2017)(Bruce et al., 2011), though, Abbas Fotouhi et al. explain the working principles of Li-S battery. In the discharge phase, solid Sulphur from the cathode dissolves into the electrolyte, 
forming $S_{8}$. Then, redox reactions take place. Intermediate products are formed at the cathode through a reduction, called lithium polysulfide species (Li2Sx). Instead, at the anode is produced an oxidation of $\mathrm{Li}$ metal to $\mathrm{Li}+$ ions. At the end of discharge, $\mathrm{S}_{8}$ is fully reduced to $\mathrm{S}^{2-}$ $\left(\mathrm{Li}_{2} \mathrm{~S}\right)$ and the anode is fully stripped of Li metal. On the other hand, in the charge phase, the reactions take place in the opposition direction, with $\mathrm{Li}+$ ions depositing at the anode as $\mathrm{Li}$ metal and low-order polysulphides oxidizing from $\mathrm{S}^{2-}$ up to $\mathrm{S}_{8}^{2-}$ and eventually $\mathrm{S}_{8}(\mathrm{~s})$ (Fotouhi et al., 2017a). This process is illustrated schematically in Figure 6.
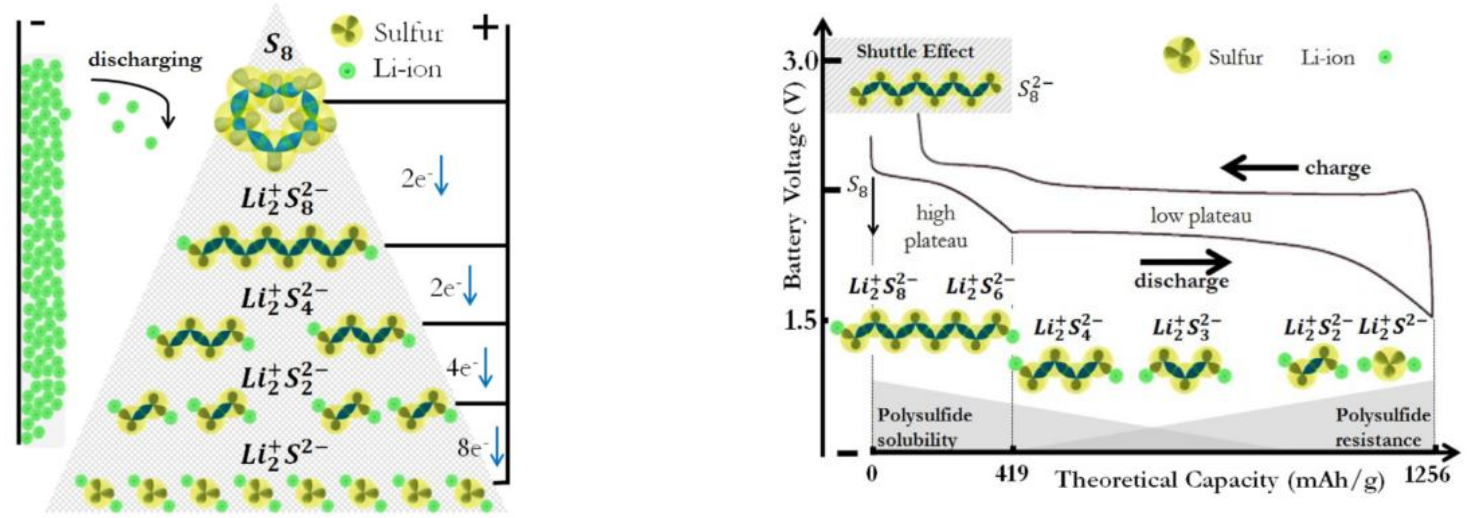

Figure 6 : (Left) Working principle of Li-S battery. (Right) Basic voltage behaviour Li-S Battery (Propp et al., 2016).

In fact, Figure 6 presents the differences of Li-ion and Li-S in relation to the discharge curve. While Li-ion have an almost continuous decrease of voltage against SOC, Li-S have a high plateau at about $2,35 \mathrm{~V}(\mathrm{OCV})$, with a majority of high order polysulphides in solution $\left(\mathrm{Li}_{2} \mathrm{~S}_{8}\right.$, $\mathrm{Li}_{2} \mathrm{~S}_{6}$ ) and a low plateau at around 2,1 $\mathrm{V}(\mathrm{OCV})$, with a majority of low order polysulphides in solution ( $\mathrm{Li}_{2} \mathrm{~S}_{4}, \mathrm{Li}_{2} \mathrm{~S}_{3}, \mathrm{Li}_{2} \mathrm{~S}_{2}, \mathrm{Li}_{2} \mathrm{~S}$ ) (Propp et al., 2016). These dips and rises in the discharge curve might cause problems to state of charge calculation (Bugga et al., 2017). These SOC estimation difficulties will be assessed in section 3.2 when studying the battery models.

Power limitations of Li-ion batteries are governed by the diffusion of ions into the electrodes, which is mainly defined by the battery design and therefore not considered to vary rapidly with normal usage. On the other hand, for Li-S batteries, power exhibits a high sensitivity to cycling parameters such as current profile or temperatures due to slow diffusion of species through the electrolyte, bottlenecks in the electrochemical reaction pathway and reduced availability of active species and/or active surfaces (for instance, due to the precipitation of lower order polysulphides). Polysulphide kinetics in the high plateau region are fast, leading to good rate capabilities and low cell resistance, but the high plateau usually accounts for merely $10 \%-30 \%$ of a cycled cell's capacity.

Additionally, polysulphides kinetics are directly related to cell voltage Figure 6 , represents the Open Circuit Voltage (OCV) against SOC. In Li-S, voltage ranges between 2,7 V when fully charged to 1,5 V when depleted. These values are almost half of those from Li-ion, directly affecting the power rates. Therefore, although Li-S have higher energy density they have lower power density than Li-ion, which is a main concern for car manufacturers (Song et al., 2013)(Nitta et al., 2015)(Yong et al., 2015). With respect to current rates, recent studies (HELIS, n.d.) have shown that Li-S cells present low values compared to Li-ion. In fact, while Li-ion cells can achieve 20-50 Ah/cell, Li-S values are about 10 times lower. This characteristic is a major issue when configuring a battery pack for EVs application. For instance, for Li-ion technology, a 
$90 \mathrm{~kW}$ battery can be obtained by connecting around 100 cells at $3,8 \mathrm{~V}$, while it is unclear how to achieve these values, with Li-S cells without achieving high C-rates.

Therefore, Li-S cells low power and high capacity as shown in Figure 6 make this chemistry more suitable for EV's than for PHEV's (Poullikkas, 2015).

Another important aspect that Li-S should improve concerns the number of cycles they can do. Long life cycles are essential for car manufacturers, as battery warranties ensure eight to ten years or 100.000 to $150.000 \mathrm{~km}$ (Canals Casals et al., 2016). Nowadays, Li-S batteries have extremely rapid decrease in capacity, lasting for less than 50 cycles (Wagner et al., 2016), (Kolosnitsyn and Karaseva, 2008), which is between 10 and 40 times less than what Li-ion commercial batteries are offering (Table 1). Moreover, Li-S batteries have 8-15\% self-discharge rate per month (Kolosnitsyn and Karaseva, 2008)(V. Knap et al., 2016) due to polysulfide shuttle (Mikhaylik and Akridge, 2004) and collector corrosion (Song et al., 2013), (Vaclav Knap et al., 2016), (Marinescu et al., 2015), which is between 10 and 15 times higher than the selfdischarge of Li-ion batteries (Table 1). Yousif et al. conducted tests at different conditions on a $21 \mathrm{Ah} \mathrm{Li-S} \mathrm{cell,} \mathrm{which} \mathrm{showed} \mathrm{that} \mathrm{self-discharge} \mathrm{is} \mathrm{more} \mathrm{significant} \mathrm{as} \mathrm{SOC} \mathrm{increases} \mathrm{(Yousif} \mathrm{et}$ al., 2018). Thus it is recommendable to store Li-s batteries at low SOC. Nonetheless, most of the applications need a battery fully charged as a starting operational point.

Even though, as explained above, the shuttle effect has several undesired consequences on Li$S$ batteries, Vaclav Knap et al. make use of this effect to introduce a new type of passive dissipative balancing method, based on electrochemistry, which allows to take better advantage of the total capacity. This intrinsic self-discharge phenomenon of Li-S batteries can be used for dissipating the energy of the unbalanced cells with higher charge (Knap et al., 2017).

As it has been explained, Li-S inherent differences compared to Li-ion lead to significant performance divergences. The shuttle effect leads to low coulombic efficiency and short lifespan. Therefore, one of the major issues is the one related to the low voltages and C-rates that Li-S can achieved, despite the high energy voltages, compared to Li-ion that represent a challenge for EV applications.

\subsection{Modelling}

Battery models for EV applications need a good balance between response speed, reliability and complexity. The differences in the working principle between Li-ion and Li-S technologies also affect battery modelling. Modelling is used to study battery designs and dimensioning in vehicles or in other stationary applications under different working conditions (temperatures, Depth of Discharge (DOD), C-rate, etc.) without the need of performing costly and time consuming experimental tests for each case (Hu et al., 2012). In the case of EVs, battery models are useful for practical and real time issues, such as indicating the available range to drivers, or for vehicle design, such as thermal management, lifespan estimation or performance optimization among others (Cheon et al., 2003). Thus, this study assumes that battery models for EV applications are focused on functional and external parameters rather than on the understanding of its chemical behaviour. Regarding batteries, most of the models are based on mathematical, electrochemical and electric equivalent approaches. 
While Li-ion batteries models are quite advanced and precise, those of Li-S are still in an embryonic stage due to the novelty of this technology and they are finding unpredictable behaviours that should be thoroughly analysed.

One of the main issues in battery modelling is SOC estimation, which in Li-ion batteries is preliminary done by Coulomb counting and voltage reading. Coulomb counting registers the amount of current passing through the battery and it can be applied while the battery is in use. However, measurements have an error that increases along time. Therefore, whenever the conditions are stable enough, SOC estimation is calibrated by means of a voltage measurement. These two methods don't apply to Li-S because coulomb counting fails due to the shuttle effect and voltage reading might mislead as a consequence of the two plateaux (non-linearity).

Temperature is another important factor that influences the voltage of the battery and in consequence the usable capacity, power, SOC estimation, etc. The effect of temperature in Liion batteries has been fully studied and today it is possible to predict and reproduce its dependence on voltage and lifespan (Lin et al., 2014), (Canals Casals et al., 2017).

In parallel to the difficulties in predicting the battery behaviour due to temperature, Li-S models should also take into account memory effect that are not fully characterized yet for Li-S technology. This problem is inexistent in Li-ion batteries. Therefore, although Li-S batteries have potential to work well in cold environments, the relation between OCV and temperature may change substantially depending on previous cycles due to memory effect (Propp et al., 2016).

Despite the differences, Li-S and Li-ion batteries models present the same factors. For example, in instant response models it might be enough to use voltage, temperature and Crate to evaluate the behaviour of a battery. However, for battery ageing and cycling degradation, models should include other factors such as DOD and the effect of time in the calendar ageing.

Regarding mathematical models, they can be both analytical and stochastic. In the first one, few equations are used to describe battery properties. Stochastic battery models, are based on the principle of the discrete-time Markov chain where one can predict the future of the process based on its present state without knowing its full history.

Electrochemical models are extremely accurate but at the same time overly complicated, needing greater capacity of data processing (Rong and Pedram, 2003), hence, they are not suitable for EVs. On the other hand, electrical circuit equivalent (ECN) models are accurate enough and have a lower complexity. Its fast response offers them the chance to work in real time conditions making them suitable for automotive applications.

Similarly, Hongwen et al. also made a comparison between the electrochemical and the ECN models concluding that ECN model performs much better for EV applications (He et al., 2012). Abbas Fotouhi et al. in (Fotouhi et al., 2016b) compares and analyses the three different battery modelling approaches (mathematical, electrochemical and ECN) both for Li-ion and Li$\mathrm{S}$, concluding that despite electrochemical models have the potential to offer extreme 
accuracy ECN models are more suitable to predict the battery behaviour for EV applications, as they can support parametrisation of different operating points and therefore they can be used to estimate SOC.

Table 2 presents a summary of the different Li-S models classified by type and ordered per year. This chronologic order shows the fact that mathematic models are the first used when a new chemistry is under development. Usually this first stage is performed at cell level. After that, the electrochemical model gains relevance in both cell and battery level to better understand the chemical reactions inside.

\begin{tabular}{|c|c|c|c|c|}
\hline Author & Year & Level & Objective & Ref. \\
\hline $\begin{array}{l}\text { Karthikeyan } \\
\text { Kumaresan }\end{array}$ & 2008 & Cell & $\begin{array}{l}\text { Physical reasons for the two- } \\
\text { stage discharge profile }\end{array}$ & $\begin{array}{l}\text { (Kumares } \\
\text { an et al., } \\
\text { 2008) }\end{array}$ \\
\hline $\begin{array}{l}\text { Mahmoudrez } \\
\text { a Ghaznavi, } \\
\text { P. Chen }\end{array}$ & 2013 & Cell & $\begin{array}{l}\text { Applied discharge current and } \\
\text { cathode conductivity }\end{array}$ & $\begin{array}{l}\text { (Ghaznavi } \\
\text { and Chen, } \\
\text { 2014a) }\end{array}$ \\
\hline $\begin{array}{l}\text { Mahmoudrez } \\
\text { a Ghaznavi, } \\
\text { P. Chen }\end{array}$ & 2013 & Cell & $\begin{array}{l}\text { Precipitation reaction kinetics } \\
\text { and Sulphur content }\end{array}$ & $\begin{array}{l}\text { (Ghaznavi } \\
\text { and Chen, } \\
\text { 2014b) }\end{array}$ \\
\hline $\begin{array}{l}\text { Mahmoudrez } \\
\text { a Ghaznavi, } \\
\text { P. Chen }\end{array}$ & 2014 & Cell & $\begin{array}{l}\text { Variation of the exchange } \\
\text { current densities, diffusion } \\
\text { coefficients, and cathode } \\
\text { thickness over a wide range }\end{array}$ & $\begin{array}{l}\text { (Ghaznavi } \\
\text { and Chen, } \\
\text { 2014c) }\end{array}$ \\
\hline $\begin{array}{l}\text { Martin Rolf } \\
\text { Busche }\end{array}$ & 2014 & Cell & $\begin{array}{l}\text { Shuttle-effect at different } \\
\text { temperatures and different rates }\end{array}$ & $\begin{array}{l}\text { (Busche } \\
\text { et al., } \\
2014 \text { ) }\end{array}$ \\
\hline Vaclav Knap & 2016 & Battery & $\begin{array}{c}\text { A self-discharge model based on } \\
\text { direct shuttle current } \\
\text { measurement }\end{array}$ & $\begin{array}{l}\text { (Vaclav } \\
\text { Knap et } \\
\text { al., 2016) }\end{array}$ \\
\hline Peng Tan & 2017 & Battery & $\begin{array}{c}\text { Mass transport and } \\
\text { electrochemical reaction } \\
\text { processes is first developed }\end{array}$ & $\begin{array}{l}\text { (Tan et } \\
\text { al., 2017) }\end{array}$ \\
\hline $\begin{array}{l}\text { Zhaofeng } \\
\text { Deng }\end{array}$ & 2013 & Battery & $\begin{array}{c}\text { Modelling and Analysis of } \\
\text { Capacity } \\
\text { Fading }\end{array}$ & $\begin{array}{l}\text { (Deng et } \\
\text { al., 2013) }\end{array}$ \\
\hline $\begin{array}{l}\text { Andreas F. } \\
\text { Hofmann }\end{array}$ & 2014 & Battery & Shuttle and capacity loss & $\begin{array}{l}\text { (Hofmann } \\
\text { et al., } \\
2014)\end{array}$ \\
\hline Teng Zhang & 2015 & Cell & $\begin{array}{l}\text { Modelling the voltage loss } \\
\text { mechanisms }\end{array}$ & $\begin{array}{l}\text { (Zhang et } \\
\text { al., 2015) }\end{array}$ \\
\hline Y.X. Ren & 2016 & Battery & $\begin{array}{l}\text { Discharge behaviour } \\
\text { incorporating the effect of } \mathrm{Li}_{2} \mathrm{~S} \\
\text { precipitation }\end{array}$ & $\begin{array}{l}\text { (Ren et } \\
\text { al., 2016) }\end{array}$ \\
\hline $\begin{array}{l}\text { Monica } \\
\text { Marinescu }\end{array}$ & 2016 & Battery & $\begin{array}{l}\text { Dimensional model during } \\
\text { charge and discharge }\end{array}$ & $\begin{array}{c}\text { (Marinesc } \\
\text { u et al., } \\
\text { 2015) }\end{array}$ \\
\hline Mahsa Ebadi & 2017 & Battery & $\begin{array}{c}\text { Modelling the Interfacial } \\
\text { Chemistry of the LiNO3 Additive }\end{array}$ & $\begin{array}{l}\text { (Ebadi et } \\
\text { al., 2017) }\end{array}$ \\
\hline
\end{tabular}




\begin{tabular}{|c|c|c|c|c|}
\hline Nisa Erisen & 2018 & Battery & $\begin{array}{l}\text { Predict the effect of critical } \\
\text { cathode design parameters }\end{array}$ & $\begin{array}{l}\text { (Erisen et } \\
\text { al., 2018) }\end{array}$ \\
\hline Vaclav Knap & 2018 & Battery & $\begin{array}{c}\text { Test Methodology for } \\
\text { Degradation Assessment }\end{array}$ & $\begin{array}{l}\text { (Knap et } \\
\text { al., 2018) }\end{array}$ \\
\hline $\begin{array}{l}\text { Monica } \\
\text { Marinescu }\end{array}$ & 2018 & Battery & $\begin{array}{c}\text { Irreversible vs Reversible } \\
\text { Capacity Fade during Cycling: } \\
\text { The Effects of Precipitation and } \\
\text { Shuttle }\end{array}$ & $\begin{array}{l}\text { (Marinesc } \\
\text { u et al., } \\
\text { 2018) }\end{array}$ \\
\hline $\begin{array}{l}\text { Saul Perez } \\
\text { Beltran }\end{array}$ & 2018 & Battery & $\begin{array}{l}\text { New understanding of graphene } \\
\text { effects on S reduction behaviour }\end{array}$ & $\begin{array}{l}\text { (PerezBel } \\
\text { tran and } \\
\text { Balbuena, } \\
\text { 2018) }\end{array}$ \\
\hline Chen & 2006 & Battery & $\begin{array}{c}\text { prediction of the remaining } \\
\text { battery capacity of Lithium-ion } \\
\text { batteries }\end{array}$ & $\begin{array}{l}\text { (Chen et } \\
\text { al., 2006) }\end{array}$ \\
\hline O. Erdinc & 2009 & Battery & $\begin{array}{l}\text { Effects of temperature and } \\
\text { capacity fading }\end{array}$ & $\begin{array}{l}\text { (Erdinc et } \\
\text { al., 2009) }\end{array}$ \\
\hline $\begin{array}{l}\text { Natalia A. } \\
\text { Cañas }\end{array}$ & 2012 & Battery & $\begin{array}{l}\text { Equivalent circuit model using } \\
\text { electrochemical impedance } \\
\text { spectroscopy }\end{array}$ & $\begin{array}{l}\text { (Cañas et } \\
\text { al. 2013) }\end{array}$ \\
\hline $\begin{array}{l}\text { Suguna } \\
\text { Thanagasund } \\
\text { ram }\end{array}$ & 2012 & Cell & Cell model for battery simulation & $\begin{array}{l}\text { (Thanaga } \\
\text { sundram } \\
\text { et al., } \\
2012 \text { ) }\end{array}$ \\
\hline Vaclav Knap & 2015 & Battery & $\begin{array}{l}\text { Parametrization Techniques for } \\
\text { an Electrical Circuit Model }\end{array}$ & $\begin{array}{c}\text { (Knap et } \\
\text { al., } \\
2015 b)\end{array}$ \\
\hline Vaclav Knap & 2015 & Battery & Performance Modelling & $\begin{array}{l}\text { (Knap et } \\
\text { al., } \\
\text { 2015a) }\end{array}$ \\
\hline $\begin{array}{l}\text { Abbas } \\
\text { Fotouhi }\end{array}$ & 2015 & Battery & $\begin{array}{l}\text { Electric Vehicle Battery Model } \\
\text { Identification and State of } \\
\text { Charge Estimation in Real World } \\
\text { Driving Cycles }\end{array}$ & $\begin{array}{l}\text { (Fotouhi } \\
\text { et al., } \\
2015 \text { ) }\end{array}$ \\
\hline $\begin{array}{l}\text { Abbas } \\
\text { Fotouhi }\end{array}$ & 2016 & Battery & $\begin{array}{c}\text { Prediction-Error Minimization } \\
\text { (PEM) algorithm applied to } \\
\text { experimental data }\end{array}$ & $\begin{array}{l}\text { (Fotouhi } \\
\text { et al., } \\
\text { 2016c) } \\
\end{array}$ \\
\hline $\begin{array}{l}\text { Abbas } \\
\text { Fotouhi }\end{array}$ & 2016 & Cell & $\begin{array}{l}\text { Graphical User Interface for } \\
\text { Battery Design and Simulation; } \\
\text { From Cell Test Data to Real- } \\
\text { World Automotive Simulation }\end{array}$ & $\begin{array}{l}\text { (Fotouhi } \\
\text { et al., } \\
\text { 2016d) }\end{array}$ \\
\hline $\begin{array}{l}\text { Abbas } \\
\text { Fotouhi }\end{array}$ & 2016 & Battery & $\begin{array}{l}\text { Model in real-time applications } \\
\text { where accuracy is important }\end{array}$ & $\begin{array}{l}\text { (Fotouhi } \\
\text { et al., } \\
\text { 2016a) }\end{array}$ \\
\hline $\begin{array}{l}\text { Karsten } \\
\text { Propp }\end{array}$ & 2016 & Battery & $\begin{array}{l}\text { Non-linear state-of-charge } \\
\text { dependent ECN model }\end{array}$ & $\begin{array}{l}\text { (Propp et } \\
\text { al., 2016) }\end{array}$ \\
\hline Ali Abdollahi & 2017 & Battery & $\begin{array}{c}\text { Optimal charging for general } \\
\text { equivalent electrical battery } \\
\text { model, and battery life } \\
\text { management. }\end{array}$ & $\begin{array}{l}\text { Abdollahi } \\
\text { et al., } \\
\text { 2017) }\end{array}$ \\
\hline
\end{tabular}




\begin{tabular}{|l|c|l|c|c|}
\hline $\begin{array}{l}\text { Abbas } \\
\text { Fotouhi }\end{array}$ & 2017 & Cell & $\begin{array}{c}\text { Equivalent Circuit Network } \\
\text { Model Parameterization and } \\
\text { Sensitivity Analysis }\end{array}$ & $\begin{array}{c}\text { (Fotouhi } \\
\text { et al., } \\
\text { 2017b) }\end{array}$ \\
\hline Vaclav Knap & 2017 & Battery & $\begin{array}{c}\text { Model to study the self- } \\
\text { balancing feature }\end{array}$ & $\begin{array}{c}\text { (Knap et } \\
\text { al., 2017) }\end{array}$ \\
\hline $\begin{array}{l}\text { Daniel-loan } \\
\text { Stroe }\end{array}$ & 2017 & Battery & $\begin{array}{c}\text { Modelling the discharge phase } \\
\text { (Stroe et } \\
\text { al., 2017) }\end{array}$ \\
\hline $\begin{array}{l}\text { Abbas } \\
\text { Fotouhi }\end{array}$ & 2017 & Battery & $\begin{array}{c}\text { SOC observability Analysis and } \\
\text { Estimation }\end{array}$ & $\begin{array}{c}\text { (Fotouhi } \\
\text { et al., } \\
\text { 2017c) }\end{array}$ \\
\hline S. E. A. Yousif & 2018 & Battery & $\begin{array}{c}\text { Self-Discharge Effects in Lithium- } \\
\text { Sulphur Equivalent Circuit } \\
\text { Networks }\end{array}$ & $\begin{array}{c}\text { (Yousif et } \\
\text { al., 2018) }\end{array}$ \\
\hline
\end{tabular}

Table 2: Li-S models classifieds by the type of model

Due to the computational limitations of the microprocessors on board EVs and that they execute many tasks besides those related to the battery; battery models implemented on EV should demand low computational resources. Thus, once the chemical functionality of the battery is understood, simplified models are better options and, for this reason, ECN models take the lead.

The parameters obtained with ECN models are directly usable in applications to know SOC, $\mathrm{SOH}, \mathrm{V}$ and the internal resistance of the battery, all these parameters are necessary for the sizing of a battery in EVs (Knap et al., 2015b).

The ECN model is constructed using elementary electrical components: resistors, capacitors and voltage sources in a circuit, as shown in Figure 7. The essential configuration of an ECN battery model is using only one resistor and one voltage source to make a circuit Figure 7a) which simulate exclusively the internal resistance of the battery. Adding RC ( Figure $7 \mathrm{~b}, \mathrm{c}$ ) pairs to the model increments its accuracy by contemplating the battery polarization characteristics (Fotouhi et al., 2016d). It is essential to accurately parametrize the different elements in the ECN model to obtain reliable results. The extensively used methods to parametrize the ECN elements are current pulse-based methods (Stroe et al., 2016; Wagner et al., 2016) and the electrochemical impedance spectroscopy (EIS) (Daowd et al., 2010; Hentunen et al., 2014; Hu et al., 2011; Lin et al., 2014; Sun et al., 2009; Thanagasundram et al., 2012; Stroe et al., 2017). Another difference between Li-ion and Li-S is that the last one, the voltage profile is substantially distinct between charge and discharge.

(a)

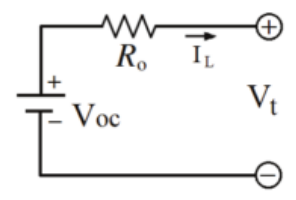

(b)

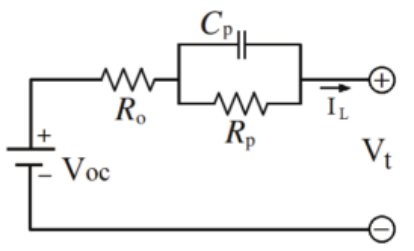

(c)

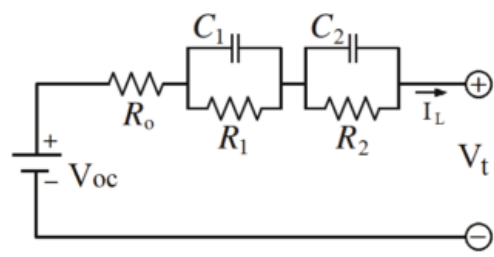

Figure 7: ECN battery model structures: (a) R model, (b) 1RC model, (c) 2RC model (Fotouhi et al., 2016d)

As a general conclusion, models for Li-ion are not transferable to Li-S model due to their differences in performance. The automotive sector is interested in simple and fast models such 
as ECN. However, as shown in Table 2, most recent studies are still struggling with electrochemical models, indicating that this technology needs more testing to be fully understood to, afterwards, develop reliable ECN models. Therefore, the current knowledge in Li-S battery behaviour has to improve in order to be applied in such ECN models and, it needs to be improved for its further application in EVs.

Additionally, in contrast to Li-ion batteries, the memory effect is a factor that should be considered carefully for Li-S modelling as it can have a major influence on the cycles above all in cold environments.

\subsection{Environmental analysis}

Li-S batteries are theoretically considered to have lower environmental impact due to the use of Sulphur, which is an element relatively abundant on Earth, that makes of it a non-toxic inexpensive material (Peled et al., 2017b). Nevertheless, this potential advantage is not fully assessed in most of the available literature concerning this technology. While there is a large number of articles that analyses Li-ion batteries from an environmental perspective, one hardly finds the same type of information for Li-S. Therefore, this paper includes a review of the findings found in some few articles regarding the environmental performance of Li-S compared to Li-ion batteries.

It should be noted that in all the references, Life Cycle Assessment methodology (LCA) has been applied as it enables a holistic characterisation of the environmental performance of the batteries. For a consistent environmental assessment, LCA should define clear boundary conditions to delimit the scope of the analysis and then consider all the steps within, such as raw materials acquisition, energy consumption to produce parts, transportation, etc...LCA studies may then cover life cycle stages up to the production of the battery (cradle-to- gate studies) or their full life cycle, including use-phase and end of life (cradle-to-grave)

The environmental impact of actual Li-ion batteries is said to be responsible of almost half of the whole environmental impact of the EV manufacture. Then, during the use-phase, the environmental impact of the EV strongly depends on the electricity mix of the country where batteries are used (Zackrisson et al., 2010), (Casals et al., 2017) and the lifespan of the battery.

To produce cathode materials for Li-ion batteries, Dunn et al. indicated that the energy consumption was considerably different for each Li-ion technology. In their study, LMO cathodes were the ones with lower energy consumption, followed by LFP cathodes that consumed half of the energy required for NMC cathode production. LCO cathodes were the ones having higher consumption, between 3 to 5 times more energy demand than LFP (Dunn et al., 2014). Similarly, the united states environmental protection agency (Amarakoon et al., 2013), studied the environmental impact of LMO, LFP and NMC electric vehicle batteries declaring that NMC cathode materials required 1.4-1.5 times as much primary energy consumption as the other two technologies. However, in contrast to the analysis from Dunn et al., this study did not only studied the amount of energy needed to build these cathodes but also analysed the stages of materials extraction, processing and manufacture, indicating that NMC batteries use rare metals such as Cobalt and Nickel that entail high human toxicity 
impacts in comparison to the other two chemistries using manganese and iron (Kang et al., 2013).

Although it was common to analyse the environmental impact regarding only the greenhouse gas (GHG) emissions taking the $\mathrm{kg}$ of equivalent $\mathrm{CO}_{2}$ emitted as the key indicator, nowadays, most environmental studies consider additional impact categories, such as materials depletion potential, toxicity and fossil resource depletion, among others.

Within these recent approaches literature agrees that LFP and LMO batteries have lower environmental impact than other Li-ion technologies. In fact, LMO performs better in some of the environmental impact categories while LFP does it in others, having a similar overall total impact (Messagie et al., 2015) except from the study by Hawkins et al. that considered that the impact from LFP and NMC batteries was similar (Hawkins et al., 2013).

The EV battery manufacture cradle-to-gate review from Kim et al. also concluded that the global warming potential (GWP) of NMC batteries was between two and three times higher than those from LMO (Kim et al., 2016). And the overall comparison of several technologies from lead acid to Li-ion batteries by Sullivan and Gaines (Sullivan and Gaines, 2012) concluded that NCA Li-ion batteries is around 3 times the environmental impact of LMO, putting them at the same level of NMC Li-ion batteries.

Therefore, NMC Li-ion batteries could be considered as the most pollutant Li-ion technology ((Hawkins et al., 2012)(Hawkins et al., 2013)) but also the one that is generally used in most EV models. Thus, this study considers that consider NMC technology for environmental analysis is a good representative (and conservative option) of Li-ion batteries when comparing with Li-S technology within an EV perspective.

This is exactly what Deng et al. did in their study, they compared Li-S against NMC Li-ion batteries. Notice that they are the sole researchers that adventured to perform an environmental impact analysis of Li-S (Deng et al., 2017). Figure 8 presents their battery manufacturing results per category taking the same order of magnitude, including ReCiPe method for impact categories characterisation (Goedkoop and Huijbregts, 2013) . 
Figure 8: Life cycle impact benchmarking between the Li-S and the NCM-Graphite battery packs (Deng et al., 2017).

Figure 8 shows the results of the comparison of Li-S and NMC Li-ion batteries. More relevant differences are found in Human Toxicity Potential (HTP) impact category, where Li-S batteries obtain an $85 \%$ lower value, followed by Materials Depletion Potential (MDP) category, with a 74\% reduction. GWP and Fossil resources Depletion Potential (FDP) have a lesser impact decrease around the $20 \%$.

From this study, it can be depicted that Li-S batteries have lower environmental impact results compared to NMC Li-ion. Firstly, Li-S batteries present a lower GWP (which is the category that better explains the impact of mankind in a globalized world) by a $20 \%$ in comparison to NMC Li-ion batteries, but its main contributions are found in huge reductions on resource depletion and human toxicity. Although results could be less favourable if Li-S batteries were compared to LFP or LMO batteries, these extreme reduction put them in a more favourable position. Moreover, we should consider that Li-S batteries are still in prototype and testing phases, which implies that there are still no industrialized manufacturing processes and, in consequence, the uncertainty of the environmental analysis for Li-S is quite higher than the ones from Li-ion batteries.

Another aspect that should be highlighted with respect to Li-S batteries is the potential formation of $\mathrm{H}_{2} \mathrm{~S}$ and $\mathrm{SO}_{2}$ gases in certain operation conditions, which is highly poisonous and leads to serious health complications and eventually death at concentrations above 1000ppm. This gas could be generated when Li-S cells achieve a temperature above 230 으 (thermal runaway) (HELIS, n.d.). Donghai Liu et al. have developed a new solution to transform $\mathrm{H}_{2} \mathrm{~S}$ and $\mathrm{SO}_{2}$ gases into water-dispersed sulphur nanoparticle (WDS) which is contaminant-free. Both $\mathrm{H}_{2} \mathrm{~S}$ and $\mathrm{SO}_{2}$ have high sulphur contents ( $94 \mathrm{wt} \%$ for $\mathrm{H}_{2} \mathrm{~S}$ and $50 \mathrm{wt} \%$ for $\mathrm{SO}_{2}$ ). These two gases with an appropriate method can be converted into useful materials for a highly-efficient Li-S battery (Liu et al., 2017). Despite the encouraging results coming from this research, it is still unclear whether this can be applied in Li-S batteries for EVs. For this reason, though the 
formation of this gas is very unlikely, Li-S batteries casing should be capable to ensure the proper sealing conditions to prevent this gas from leaking during tests or in operation phases.

In conclusion, from these initial studies, it can be stated that Li-S batteries present lower environmental impacts compared to Li-ion and there is still margin to improve once Li-S technology will become commercial and industrial scale manufactured.

\subsection{Cost analysis}

Literature emphasizes that one of the most important aspects of Li-S regarding Li-ion is its lower cost (Chen and Shaw, 2014; Cheon et al., 2003; Kolosnitsyn and Karaseva, 2008; Manthiram et al., 2015; Nazar et al., 2014; Nitta et al., 2015; Wild et al., 2015). For this reason, Table 3 presents a comparison of the cost per kilogram of the most relevant elements from different Li-ion and Li-S batteries. Notice that Table 3 considers the three Li-ion battery variants with higher practical specific energy $(\mathrm{Wh} / \mathrm{kg}$ ); LCO (Lithium Cobalt Oxide), NMC (Lithium Nickel Cobalt Manganese Oxide) and NCA (Lithium Nickel Cobalt Aluminium Oxide). Consequently, the chemical elements presented are Cobalt, Nickel, Manganese, Aluminium and Sulphur.

\begin{tabular}{|c|c|c|c|c|c|c|}
\hline \multicolumn{7}{|c|}{ Unit value (\$/t) } \\
\hline Year & Lithium & Aluminium & Cobalt & Nickel & Manganese & Sulphur \\
\hline 2000 & 4.470 & 1.640 & 29.700 & 8.640 & 582 & 24,70 \\
\hline 2001 & 1.490 & 1.520 & 23.300 & 5.950 & 529 & 10,00 \\
\hline 2002 & 1.590 & 1.430 & 17.100 & 6.770 & 471 & 11,80 \\
\hline 2003 & 1.550 & 1.500 & 20.600 & 9.630 & 599 & 28,70 \\
\hline 2004 & 1.720 & 1.850 & 43.400 & 13.800 & 1.090 & 32,60 \\
\hline 2005 & 1.460 & 2.010 & 33.600 & 14.700 & 712 & 30,80 \\
\hline 2006 & 2.320 & 2.680 & 30.700 & 24.200 & 800 & 32,90 \\
\hline 2007 & 3.530 & 2.690 & 54.600 & 37.200 & 1.190 & 32,90 \\
\hline 2008 & 4.440 & 2.660 & 68.400 & 21.100 & 2.380 & 264 \\
\hline 2009 & 4.530 & 1.750 & 34.200 & 14.600 & 1.370 & 1,70 \\
\hline 2010 & 4.350 & 2.300 & 39.700 & 21.800 & 1.500 & 70,20 \\
\hline 2011 & 3.870 & 2.560 & 36.100 & 22.900 & 1.460 & 160,00 \\
\hline 2012 & 4.220 & 2.230 & 30.500 & 17.500 & 1.400 & 124,00 \\
\hline 2013 & 6.800 & 2.080 & 28.400 & 15.000 & 1.620 & 68,70 \\
\hline 2014 & 6.690 & 2.300 & 31.900 & 16.900 & 1.350 & 80,10 \\
\hline 2015 & 6.500 & 1.940 & 29.600 & 11.800 & 1.210 & 87,60 \\
\hline 2016 & 8.650 & 1.800 & 26.400 & 9.500 & 1.780 & 37,88 \\
\hline 2017 & 13.900 & 2.200 & 58.600 & 10.100 & 1.900 & 60,00 \\
\hline Average & 4.560 & $\mathbf{2 . 0 6 3}$ & $\mathbf{3 5 . 3 7 8}$ & $\mathbf{1 5 . 6 7 2}$ & $\mathbf{1 . 2 1 9}$ & $\mathbf{6 4}$ \\
\hline
\end{tabular}

Table 3: List of element prices of the analysed batteries (USGS, 2017).

\begin{tabular}{|l|c|c|c|c|c|c|}
\hline \multicolumn{7}{|c|}{ World production (tons) } \\
\hline Year & Lithium & Aluminium & Cobalt & Nickel & Manganese & Sulphur \\
\hline 2000 & 204.000 & 24.300 .000 & 39.300 & 1.290 .000 & 6.960 .000 & 59.300 .000 \\
\hline 2015 & 604.000 & 57.500 .000 & 126.000 & 2.280 .000 & 17.500 .000 & 68.900 .000 \\
\hline Increase & $\mathbf{1 9 6 \%}$ & $\mathbf{1 3 7 \%}$ & $\mathbf{2 2 1 \%}$ & $\mathbf{7 7 \%}$ & $\mathbf{1 5 1 \%}$ & $\mathbf{1 6 \%}$ \\
\hline \multicolumn{7}{|c|}{ Table 4: World production of the elements of the analysed batteries (USGS, 2017). }
\end{tabular}


Considering that the amount of materials needed for battery production is a small portion of the global demand, the variability of prices in Table 3 should not be attributed to the variations of battery production, being hard to draw any logical correlation between prices. Regarding Sulphur, Table 3 shows how its price is much lower than all the other elements used in Li-ion batteries. Moreover, Table 4 presents how, except form Sulphur, all the elements doubled or tripled the world's demand.

In fact, the price of Sulphur is 32 times cheaper than Aluminium, 243 times cheaper than Nickel, 550 times cheaper than Cobalt and 20 times cheaper than Manganese. In order to confirm the Li-S battery price reduction in comparison to Li-ion, it is necessary to know their manufacturing costs. Unfortunately, Li-S batteries are still not commercialized, thus, this comparison cannot be performed. The development of large-scale, low-cost fabrication strategies for electrode materials with desirable performance represents an important challenge in the development of cost-effective Lithium/Sulphur cells (Song et al., 2013). Analysing prices in Table 3, it is appreciable that Lithium and Cobalt, which are the materials with higher prices, have a bull trend. Furthermore, Lithium and Cobalt according to (Helbig et al., 2018), present a big uncertainty as a consequence of the dependence of the batteries with these materials. Even though the price of Sulphur does not follow any logical trend, their great availability and lower values position it within a certain advantage towards the actual Li-ion technology. Isidor Buchmann said that a price of US\$250 per kWh of Li-S battery is possible (Isidor Buchmann, 2016), on the contrary, Abbas Fotouhi et al. prognosticate a more aggressive price (around $\$ 100$ per $\mathrm{kWh}$ ) (Fotouhi et al., 2017a).

Erik J. Berg et al. made a cost comparison between NMC (Li-ion) and Li-S batteries and the price difference of the cathode is considerable. The NMC cathode would have a cost of $33 \$ / \mathrm{kg}$ when for Li-S would be $0.05 € / \mathrm{kg}$ (Berg and Trabesinger, 2018). Note that the cost of the NMC cathode is 660 times greater, which reaffirms that our comparison between the elementary components of these batteries can be taken as correct.

\section{Conclusions}

After the analysis of the different key parameters required for EV applications, this study reports that Li-S are clearly ahead of Li-ion batteries in four of the analysed parameters. As shown in Table 5, these four key aspects are energy density, safety, price and environmental impact. On the contrary, Li-S batteries are rather less interesting in other important aspects such as lifecycle, self-discharge, power density and modelling.

\begin{tabular}{lccccc} 
& \multicolumn{5}{c}{ Li-ion } \\
& NMC & NCA & LCO & LFP & Li-S \\
\hline Energy density & + & + & + & +- & +++ \\
\hline Power density & ++ & ++ & ++ & + & +- \\
\hline Lifecycle & ++ & +- & + & ++ & -- \\
\hline Self-discharge & ++ & ++ & ++ & ++ & -- \\
\hline Safety & + & - & - & +- & + \\
\hline Price & - & +- & +- & + & +++ \\
\hline Model & ++ & ++ & + & +- & - \\
\hline Environmental & - & - & -- & +- & ++ \\
\hline
\end{tabular}


Although both technologies (Li-S and Li-ion) can still improve their performances, Li-ion batteries are currently closer to their theoretical energy density limit than Li-S. This characteristic gives Li-S good perspectives and chances to be implemented in EVs in the nearby future. In addition, Li-S batteries are better qualified than Li-ion ones in safety (better), price (lower) and environmental impact (lower).

In fact, concerning the environmental aspects, Li-S preliminary results show that this technology is being far less harmful for humankind, reducing the GWP and the resource depletion than NMC Li-ion batteries, these results should be used carefully, as the manufacturing processes of Li-S batteries are not industrialized in contrast to those of Li-ion and they might change substantially.

Nonetheless, these four positive aspects are not enough for Li-S to substitute Li-ion batteries in EV applications. This study shows how the main drawbacks for Li-S concern durability, selfdischarge and battery modelling. As it has been explained, Li-S chemical characteristics lead to undesired effects (such as shuttle and cathode expansion) that provoke low coulombic efficiency and short lifespan. Therefore, Li-S despite their high energy voltages compared to Liion, represent a challenge for EV applications.

Nowadays, Li-S battery modelling focus the attention on electrochemical models, to fully understand its behaviour, and are now doing their first steps into ECN models, which are the ones preferred for EV applications.

In order to have real opportunities to substitute Li-ion, Li-S batteries should get closer to Li-ion on at least three parameters: durability, self-discharge and modelling. Knowing the potential and advantages of Li-S batteries, research should now focus the attention in these three aspects rather than trying to improve the aspects were they are already good enough.

\section{References}

Abruña, J.G. and H.D., 2014. Key Parameters Governing the Energy Density of Rechargeable Li/S Batteries. Phys. Chem. Lett.

Adams, B.D., Carino, E. V, Connell, J.G., Sung, K., Cao, R., Chen, J., Zheng, J., Li, Q., Mueller, K.T., Henderson, W.A., 2017. Nano Energy Long term stability of Li-S batteries using high concentration lithium nitrate electrolytes. Nano Energy 40, 607-617. doi:10.1016/j.nanoen.2017.09.015

ALISE, n.d. ALISE Project website [WWW Document]. URL http://www.aliseproject.com/ (accessed 7.30.18).

Amarakoon, S., Smith, J., Segal, B., 2013. Application of Life-Cycle Assessment to Nanoscale Technology: Lithium-ion Batteries for Electric Vehicles. United States Environ. Prot. Agency 25, 1-119. doi:10.1038/nchem.2085

Barchasz, C., Molton, F., Duboc, C., Leprêtre, J.C., Patoux, S., Alloin, F., 2012. Lithium/sulfur cell discharge mechanism: An original approach for intermediate species identification. Anal. Chem. 84, 3973-3980. doi:10.1021/ac2032244 
Barghamadi, M., Kapoor, A., Wen, C., 2013. A Review on Li-S Batteries as a High Efficiency Rechargeable Lithium Battery. J. Electrochem. Soc. 160, 1256-1263. doi:10.1149/2.096308jes

Berg, E.J., Trabesinger, S., 2018. Viability of Polysulfide-Retaining Barriers in Li-S Battery. J. Electrochem. Soc. 165, A5001-A5005. doi:10.1149/2.0021801jes

Bonges, H.A., Lusk, A.C., 2016. Addressing electric vehicle (EV) sales and range anxiety through parking layout, policy and regulation. Transp. Res. Part A Policy Pract. 83, 63-73. doi:10.1016/j.tra.2015.09.011

Bresser, D., Passerini, S., Scrosati, B., 2013. Recent progress and remaining challenges in sulfurbased lithium secondary batteries - a review. Chem. Commun. Chem. Commun 49, 10545-10562. doi:10.1039/c3cc46131a

Bruce, P.G., Freunberger, S.A., Hardwick, L.J., Tarascon, J.-M., 2011. Li-O2 and Li-S batteries with high energy storage. Nat. Mater. 11, 172-172. doi:10.1038/nmat3237

Buchmann, I., 2016. Batteries in a portable world : a handbook on rechargeable batteries for non-engineers, Fourth edi. ed.

Buchmann, I., 2016. Batteries In A Portable World, Fourth Edi. ed. Founder \& CEO Cadex Electronics Inc.

Bugga, K., Jones, S., Pasalic, J., Jones, J., Krause, C., 2017. HIGH ENERGY AND LONG-LIFE LITHIUM-SULFUR CELLS. Li-SM3 2017 Conf.

Busche, M.R., Adelhelm, P., Sommer, H., Schneider, H., Leitner, K., Janek, J., 2014. Systematical electrochemical study on the parasitic shuttle-effect in lithium-sulfur-cells at different temperatures and different rates. J. Power Sources 259, 289-299. doi:10.1016/j.jpowsour.2014.02.075

Canals Casals, L., Amante García, B., González Benítez, M.M., 2017. Aging Model for Re-used Electric Vehicle Batteries in Second Life Stationary Applications, in: J.L. Ayuso Muñoz (Ed.), Project Management and Engineering Research. pp. 139-151. doi:10.1007/978-3319-51859-6

Canals Casals, L., Miguel, A., González, S., Amante García, B., Llorca, J., 2016. PHEV Battery Aging Study Using Voltage Recovery and Internal Resistance From Onboard Data 65, 4209-4216.

Cañas, N.A., Hirose, K., Pascucci, B., Wagner, N., Friedrich, K.A., Hiesgen, R., 2013. Investigations of lithium-sulfur batteries using electrochemical impedance spectroscopy. Electrochim. Acta 97, 42-51. doi:10.1016/j.electacta.2013.02.101

Casals, L.C., García, B.A., Aguesse, F., Iturrondobeitia, A., 2017. Second life of electric vehicle batteries : relation between materials degradation and environmental impact. Int. J. Life Cycle Assess. 22, 82-93. doi:10.1007/s11367-015-0918-3

Chen, L., Shaw, L.L., 2014. Recent advances in lithium e sulfur batteries. J. Power Sources 267, 770-783. doi:10.1016/j.jpowsour.2014.05.111

Chen, M., Member, S., Rinc, G.A., 2006. Accurate Electrical Battery Model Capable of Predicting Runtime and I-V Performance 21, 504-511. 
Chen, R., Zhao, T., Tian, T., Cao, S., Coxon, P.R., Xi, K., Fairen-Jimenez, D., Vasant Kumar, R., Cheetham, A.K., 2014. Graphene-wrapped sulfur/metal organic framework-derived microporous carbon composite for lithium sulfur batteries. APL Mater. 2. doi:10.1063/1.4901751

Cheon, S.-E., Ko, K.-S., Cho, J.-H., Kim, S.-W., Chin, E.-Y., Kim, H.-T., 2003. Rechargeable Lithium Sulfur Battery. J. Electrochem. Soc. 150, A800. doi:10.1149/1.1571533

Climate, G., Project, E., 2006. Global Climate \& Energy Project Technical Assessment Report A Technical Assessment of High-Energy Batteries for Light-Duty Electric Vehicles.

Daowd, M., Omar, N., Verbrugge, B., Bossche, P. Van Den, Mierlo, J. Van, 2010. Battery Models Parameter Estimation based on Matlab / Simulink ${ }^{\circledR}$. 25th World Batter. Hybrid Fuel Cell Electr. Veh. Symp. Exhib. Batter. 2, 1-6.

Deng, Y., Li, J., Li, T., Gao, X., Yuan, C., 2017. Life cycle assessment of lithium sulfur battery for electric vehicles. J. Power Sources 343, 284-295. doi:10.1016/j.jpowsour.2017.01.036

Deng, Z., Zhang, Z., Lai, Y., Liu, J., Li, J., Liu, Y., 2013. Electrochemical Impedance Spectroscopy Study of a Lithium/Sulfur Battery: Modeling and Analysis of Capacity Fading. J. Electrochem. Soc. 160, A553-A558. doi:10.1149/2.026304jes

Diao, Y., Xie, K., Xiong, S., Hong, X., 2013. Shuttle phenomenon-The irreversible oxidation mechanism of sulfur active material in Li-S battery. J. Power Sources 235, 181-186. doi:10.1016/j.jpowsour.2013.01.132

Dunn, J.B., Gaines, L., Kelly, J.C., James, C., Gallagher, K.G., Gaines, L., Gallagher, K.G., Dai, Q., Kelly, J.C., 2014. Material and Energy Flows in the Production of Cathode and Anode Materials for Lithium Ion Batteries. Argonne Natl. Lab. 1-5. doi:10.1007/s13398-0140173-7.2

Ebadi, M., Lacey, M.J., Brandell, D., Araujo, C.M., 2017. Density Functional Theory Modeling the Interfacial Chemistry of the $\mathrm{LiNO}_{3}$ Additive for Lithium-Sulfur Batteries by Means of Simulated Photoelectron Spectroscopy. J. Phys. Chem. C 121, 23324-23332. doi:10.1021/acs.jpcc.7b07847

ECLIPSE, n.d. ECLIPSE Project website [WWW Document]. URL https://eclipseh2020.eu/about/project-concept (accessed 7.30.18).

Eow, J.S., 2002. Recovery of Sulfur from Sour Acid Gas : A Review of the Technology 143-162.

EP, 2011. REGULATION (EU) No 510/2011 OF THE EUROPEAN PARLIAMENT AND OF THE COUNCIL of 11 May 2011: CO² Efficiency. Off. J. Eur. Union 2011, 18.

Erdinc, O., Vural, B., Uzunoglu, M., 2009. A dynamic lithium-ion battery model considering the effects of temperature and capacity fading 383-386.

Erisen, N., Emerce, N.B., Erensoy, S.C., Eroglu, D., 2018. Modeling the effect of key cathode design parameters on the electrochemical performance of a lithium-sulfur battery. Int. J. Energy Res. 4-6. doi:10.1002/er.4045

EUROLIS, n.d. EUROLIS Project website [WWW Document]. URL http://www.eurolis.eu/project/ (accessed 7.30.18).

Fang, X., Peng, H., 2015. A Revolution in Electrodes: Recent Progress in Rechargeable Lithium- 
Sulfur Batteries. Small 11, 1488-1511. doi:10.1002/smll.201402354

Fotouhi, A., Auger, D., O’Neill, L., Cleaver, T., Walus, S., 2017a. Lithium-Sulfur Battery Technology Readiness and Applications-A Review. Energies 10, 1937. doi:10.3390/en10121937

Fotouhi, A., Auger, D.J., Member, S., Propp, K., Longo, S., Member, S., 2016a. Accuracy Versus Simplicity in Online Battery Model Identification 1-12.

Fotouhi, A., Auger, D.J., Member, S., Propp, K., Member, S., Purkayastha, R., Neill, L.O., Walus, S., 2017b. Lithium-Sulfur Cell Equivalent Circuit Network Model Parameterization and Sensitivity Analysis. doi:10.1109/TVT.2017.2678278

Fotouhi, A., Auger, D.J., Propp, K., Longo, S., 2017c. Lithium-Sulfur Battery State-of-Charge Observability Analysis and Estimation. IEEE Trans. Power Electron. 1-1. doi:10.1109/TPEL.2017.2740223

Fotouhi, A., Auger, D.J., Propp, K., Longo, S., Wild, M., 2016b. A review on electric vehicle battery modelling: From Lithium-ion toward Lithium-Sulphur. Renew. Sustain. Energy Rev. 56, 1008-1021. doi:10.1016/j.rser.2015.12.009

Fotouhi, A., Auger, D.J.D.J., Propp, K., Longo, S., 2016c. Electric Vehicle Battery Parameter Identification and SOC Observability Analysis: NiMH and Li-S Case Studies. 8th IET Int. Conf. Power Electron. Mach. Drives (PEMD 2016) 10, 1-6. doi:10.1049/cp.2016.0142

Fotouhi, A., Propp, K., Auger, D.J., 2015. Electric vehicle battery model identification and state of charge estimation in real world driving cycles. 2015 7th Comput. Sci. Electron. Eng. Conf. 243-248. doi:10.1109/CEEC.2015.7332732

Fotouhi, A., Shateri, N., Auger, D.J., Longo, S., Propp, K., 2016d. A MATLAB Graphical User Interface for Battery Design and Simulation ; From Cell Test Data to Real-World Automotive Simulation.

Gao, J., Abruña, H.D., 2014. Key parameters governing the energy density of rechargeable Li/S batteries. J. Phys. Chem. Lett. 5, 882-885. doi:10.1021/jz5001819

Ghaznavi, M., Chen, P., 2014a. Sensitivity analysis of a mathematical model of lithium-sulfur cells part I: Applied discharge current and cathode conductivity. J. Power Sources 257, 394-401. doi:10.1016/j.jpowsour.2013.10.135

Ghaznavi, M., Chen, P., 2014b. Sensitivity analysis of a mathematical model of lithium e sulfur cells : Part II : Precipitation reaction kinetics and sulfur content. J. Power Sources 257, 402-411. doi:10.1016/j.jpowsour.2013.12.145

Ghaznavi, M., Chen, P., 2014c. Electrochimica Acta Analysis of a Mathematical Model of Lithium-Sulfur Cells Part III : Electrochemical Reaction Kinetics, Transport Properties and Charging. Electrochim. Acta 137, 575-585. doi:10.1016/j.electacta.2014.06.033

Goedkoop, M., Huijbregts, M., 2013. ReCiPe 2008 Characterisation 4-20.

Hackbarth, A., Madlener, R., 2013. Consumer preferences for alternative fuel vehicles : A discrete choice analysis 25, 5-17. doi:10.1016/j.trd.2013.07.002

Hagen, M., Hanselmann, D., Ahlbrecht, K., Maça, R., Gerber, D., Tübke, J., 2015. Lithium-Sulfur Cells: The Gap between the State-of-the-Art and the Requirements for High Energy 
Battery Cells. Adv. Energy Mater. 5. doi:10.1002/aenm.201401986

Hawkins, T.R., Gausen, O.M., Strømman, A.H., 2012. Environmental impacts of hybrid and electric vehicles-a review. Int. J. Life Cycle Assess. 17, 997-1014. doi:10.1007/s11367012-0440-9

Hawkins, T.R., Singh, B., Majeau-Bettez, G., Strømman, A.H., Strømman, A.H., 2013. Comparative Environmental Life Cycle Assessment of Conventional and Electric Vehicles. J. Ind. Ecol. 17, 53-64. doi:10.1111/j.1530-9290.2012.00532.x

He, H., Xiong, R., Guo, H., Li, S., 2012. Comparison study on the battery models used for the energy management of batteries in electric vehicles. Energy Convers. Manag. 64, 113121. doi:10.1016/j.enconman.2012.04.014

Helbig, C., Bradshaw, A.M., Wietschel, L., Thorenz, A., Tuma, A., 2018. Supply risks associated with lithium-ion battery materials. J. Clean. Prod. 172, 274-286.

doi:10.1016/j.jclepro.2017.10.122

HELIS, n.d. HELIS project website [WWW Document]. URL www.helis-project.eu (accessed 7.30.18).

Hentunen, A., Lehmuspelto, T., Suomela, J., 2014. Time-domain parameter extraction method for thevenin-equivalent circuit battery models. IEEE Trans. Energy Convers. 29, 558-566. doi:10.1109/TEC.2014.2318205

Hofmann, A.F., Fronczek, D.N., Bessler, W.G., 2014. Mechanistic modeling of polysulfide shuttle and capacity loss in lithium-sulfur batteries. J. Power Sources 259, 300-310. doi:10.1016/j.jpowsour.2014.02.082

$\mathrm{Hu}, \mathrm{X}$., Li, S., Peng, H., 2012. A comparative study of equivalent circuit models for Li-ion batteries. J. Power Sources 198, 359-367. doi:10.1016/j.jpowsour.2011.10.013

Hu, X., Sun, F., Cheng, X., 2011. Recursive calibration for a lithium iron phosphate battery for electric vehicles using extended Kalman filtering. J. Zhejiang Univ. A 12, 818-825. doi:10.1631/jzus.A1100141

IEA, I.E.A., 2017. Global EV Outlook 2017: Two million and counting. IEA Publ. 1-71. doi:10.1787/9789264278882-en

Kang, D.H.P., Chen, M., Ogunseitan, O.A., 2013. Potential Environmental and Human Health Impacts of Rechargeable Lithium Batteries in Electronic Waste. Environ. Sci. Technol. 47, 5495-5503. doi:10.1021/es400614y

Kang, W., Deng, N., Ju, J., Li, Q., Wu, D., Ma, X., Li, L., Naebe, M., Cheng, B., 2016. A review of recent developments in rechargeable lithium-sulfur batteries. Nanoscale 1, 1654116588. doi:10.1039/C6NR04923K

Kim, H.C., Wallington, T.J., Arsenault, R., Bae, C., Ahn, S., Lee, J., 2016. Cradle-to-Gate Emissions from a Commercial Electric Vehicle Li-Ion Battery: A Comparative Analysis. Environ. Sci. Technol. 50, 7715-7722. doi:10.1021/acs.est.6b00830

Knap, V., Stroe, D.-I., Purkayastha, R., Walus, S., Auger, D.J., Fotouhi, A., Propp, K., 2018. Reference Performance Test Methodology for Degradation Assessment of Lithium-Sulfur Batteries. J. Electrochem. Soc. 165, A1601-A1609. doi:10.1149/2.0121809jes 
Knap, V., Stroe, D.-I., Swierczynski, M., Purkayastha, R., Propp, K., Teodorescu, R., Schaltz, E., 2016. A self-discharge model of Lithium-Sulfur batteries based on direct shuttle current measurement. J. Power Sources 336, 325-331. doi:10.1016/j.jpowsour.2016.10.087

Knap, V., Stroe, D.-I., Swierczynski, M., Teodorescu, R., Schaltz, E., 2016. Investigation of the Self-Discharge Behavior of Lithium-Sulfur Batteries. J. Electrochem. Soc. 163, A911-A916. doi:10.1149/2.0641606jes

Knap, V., Stroe, D., Teodorescu, R., Swierczynski, M., Stanciu, T., 2015a. Electrical Circuit Models for Performance Modeling of Lithium-Sulfur Batteries 1375-1381. doi:10.1109/ECCE.2015.7309853

Knap, V., Stroe, D.I., Christensen, A.E., Propp, K., Fotouhi, A., Auger, D.J., Schaltz, E., Teodorescu, R., 2017. Self-balancing feature of Lithium-Sulfur batteries. J. Power Sources 372, 245-251. doi:10.1016/j.jpowsour.2017.10.078

Knap, V., Stroe, D.I., Teodorescu, R., Swierczynski, M., Stanciu, T., 2015b. Comparison of parametrization techniques for an electrical circuit model of Lithium-Sulfur batteries. Proceeding - 2015 IEEE Int. Conf. Ind. Informatics, INDIN 2015 1278-1283. doi:10.1109/INDIN.2015.7281919

Kolosnitsyn, V.S., Karaseva, E. V., 2008. Lithium-sulfur batteries: Problems and solutions. Russ. J. Electrochem. 44, 506-509. doi:10.1134/S1023193508050029

Kumaresan, K., Mikhaylik, Y., White, R.E., 2008. A Mathematical Model for a Lithium-Sulfur Cell. J. Electrochem. Soc. 155, A576. doi:10.1149/1.2937304

Lin, X., Perez, H.E., Mohan, S., Siegel, J.B., Stefanopoulou, A.G., Ding, Y., Castanier, M.P., 2014. A lumped-parameter electro-thermal model for cylindrical batteries. J. Power Sources 257, 1-11. doi:10.1016/j.jpowsour.2014.01.097

Liu, D., Zhang, C., Xu, Z., Zhang, L., Lv, W., Zou, X., Kang, F., Zhi, L., Cheng, H.M., Yang, Q.H., 2017. H2S + SO2produces water-dispersed sulfur nanoparticles for lithium-sulfur batteries. Nano Energy 41, 665-673. doi:10.1016/j.nanoen.2017.10.020

Lv, D., Zheng, J., Li, Q., Xie, X., Ferrara, S., Nie, Z., Mehdi, L.B., Browning, N.D., Zhang, J.G., Graff, G.L., Liu, J., Xiao, J., 2015. High Energy Density Lithium-Sulfur Batteries: Challenges of Thick Sulfur Cathodes. Adv. Energy Mater. 5, 1-8. doi:10.1002/aenm.201402290

Manthiram, A., Chung, S.-H., Zu, C., 2015. Lithium-Sulfur Batteries: Progress and Prospects. Adv. Mater. 27, 1980-2006. doi:10.1002/adma.201405115

Manthiram, A., Fu, Y., Su, Y.-S., 2013. Challenges and Prospects of Lithium-Sulfur Batteries. Acc. Chem. Res. 46, 1125-1134. doi:10.1021/ar300179v

Marinescu, M., O'Neill, L., Zhang, T., Walus, S., Wilson, T.E., Offer, G.J., 2018. Irreversible vs Reversible Capacity Fade of Lithium-Sulfur Batteries during Cycling: The Effects of Precipitation and Shuttle. J. Electrochem. Soc. 165, A6107-A6118. doi:10.1149/2.0171801jes

Marinescu, M., Zhang, T., Offer, G.J., 2015. A zero dimensional model of lithium-sulfur batteries during charge and discharge. Phys. Chem. Chem. Phys. 18, 584-593. doi:10.1039/C5CP05755H

Messagie, M., Oliveira, L., Rangaraju, S., Forner, J.S., Rivas, M.H., 2015. Environmental 
performance of lithium batteries, Rechargeable Lithium Batteries. Elsevier Ltd. doi:10.1016/B978-1-78242-090-3.00011-0

Mikhaylik, Y. V., Akridge, J.R., 2004. Polysulfide Shuttle Study in the Li/S Battery System. J. Electrochem. Soc. 151, A1969. doi:10.1149/1.1806394

Nazar, L.F., Cuisinier, M., Pang, Q., 2014. Lithium-sulfur batteries. MRS Bull. 39, 436-442. doi:10.1557/mrs.2014.86

Nitta, N., Wu, F., Lee, J.T., Yushin, G., 2015. Li-ion battery materials: Present and future. Mater. Today 18, 252-264. doi:10.1016/j.mattod.2014.10.040

Peled, E., Goor, M., Schektman, I., Mukra, T., Shoval, Y., Golodnitsky, D., 2017a. The Effect of Binders on the Performance and Degradation of the Lithium/Sulfur Battery Assembled in the Discharged State. J. Electrochem. Soc. 164, A5001-A5007. doi:10.1149/2.0161701jes

Peled, E., Goor, M., Schektman, I., Mukra, T., Shoval, Y., Golodnitsky, D., 2017b. The Effect of Binders on the Performance and Degradation of the Lithium/Sulfur Battery Assembled in the Discharged State. J. Electrochem. Soc. 164, A5001-A5007. doi:10.1149/2.0161701jes

Peled, E., Shekhtman, I., Mukra, T., Goor, M., Belenkaya, I., Golodnitsky, D., 2018. Improving the Durability and Minimizing the Polysulfide Shuttle in the Li/S Battery. J. Electrochem. Soc. 165, A6051-A6057. doi:10.1149/2.0101801jes

Peng, H.J., Huang, J.Q., Cheng, X.B., Zhang, Q., 2017. Review on High-Loading and High-Energy Lithium-Sulfur Batteries. Adv. Energy Mater. 7, 1-54. doi:10.1002/aenm.201700260

PerezBeltran, S., Balbuena, P.B., 2018. Formation of Multilayer Graphene Domains with Strong Sulfur-Carbon Interaction and Enhanced Sulfur Reduction Zones for Lithium-Sulfur Battery Cathodes. ChemSusChem. doi:10.1002/cssc.201702446

Pope, M.A., Aksay, I.A., 2015. Structural Design of Cathodes for Li-S Batteries. Adv. Energy Mater. 5, 1-22. doi:10.1002/aenm.201500124

Poullikkas, A., 2015. Sustainable options for electric vehicle technologies. Renew. Sustain. Energy Rev. 41, 1277-1287. doi:10.1016/j.rser.2014.09.016

Propp, K., Marinescu, M., Auger, D.J., Neill, L.O., Fotouhi, A., Somasundaram, K., Offer, G.J., Minton, G., Longo, S., Wild, M., Knap, V., 2016. Multi-temperature state-dependent equivalent circuit discharge model for lithium-sulfur batteries. J. Power Sources 328, 289-299. doi:10.1016/j.jpowsour.2016.07.090

Ren, Y.X., Zhao, T.S., Liu, M., Tan, P., Zeng, Y.K., 2016. Modeling of lithium-sulfur batteries incorporating the effect of Li2S precipitation. J. Power Sources 336, 115-125. doi:10.1016/j.jpowsour.2016.10.063

Rong, P., Pedram, M., 2003. An analytical model for predicting the remaining battery capacity of lithium-ion batteries. Proc. -Design, Autom. Test Eur. DATE 14, 1148-1149. doi:10.1109/DATE.2003.1253775

Schiffer, A., 2016. Thermal analysis and modelization of li-ion batteries used in electric and hybrid vehicles. Universitat Politècnica de Catalunya.

Song, M., Cairns, J., Zhang, Y., 2013. Lithium/sulfur batteries with high specific energy: old challenges and new opportunities. RSC Publ. 2186-2204. doi:10.1039/c2nr33044j 
Stroe, D.-I., Swierczynski, M., Stroe, A.-I., Knudsen Kær, S., 2016. Generalized Characterization Methodology for Performance Modelling of Lithium-Ion Batteries. Batteries 2, 37. doi:10.3390/batteries2040037

Stroe, D.I., Knap, V., Swierczynski, M., Schaltz, E., 2017. Electric circuit modeling of lithiumsulfur batteries during discharging state. 2017 IEEE Energy Convers. Congr. Expo. ECCE 2017 2017-Janua, 1024-1029. doi:10.1109/ECCE.2017.8095899

Sullivan, J.L., Gaines, L., 2012. Status of life cycle inventories for batteries. Energy Convers. Manag. 58, 134-148. doi:10.1016/j.enconman.2012.01.001

Sun, L., Zhao, Q., Xiang, J., Shi, J., Wang, L., Hu, S., Su, S., 2009. Adsorption of NO and NH3 over $\mathrm{CuO} / \mathrm{Y}$-Al2O3 catalyst by DRIFTS. Huagong Xuebao/CIESC J. 60, 444-449. doi:10.1007/s11771

Tan, P., Ni, M., Chen, B., Kong, W., Kong, W., Shao, Z., 2017. Numerical investigation of a nonaqueous lithium-oxygen battery based on lithium superoxide as the discharge product. Appl. Energy 203, 254-266. doi:10.1016/j.apenergy.2017.05.185

Thackeray, M.M., Wolverton, C., Isaacs, E.D., 2012. Electrical energy storage for transportation-approaching the limits of, and going beyond, lithium-ion batteries. Energy Environ. Sci. 5, 7854. doi:10.1039/c2ee21892e

Thanagasundram, S., Arunachala, R., Makinejad, K., Teutsch, T., Jossen, A., 2012. A Cell Level Model for Battery Simulation. Eur. Electr. Veh. Congr. 1-13.

USGS, 2017. USGS National Minerals Information Center [WWW Document]. URL https://minerals.usgs.gov/minerals/

Väyrynen, A., Salminen, J., 2012. Lithium ion battery production. J. Chem. Thermodyn. 46, 8085. doi:10.1016/j.jct.2011.09.005

Wadia, C., Albertus, P., Srinivasan, V., 2011. Resource constraints on the battery energy storage potential for grid and transportation applications. J. Power Sources 196, 15931598. doi:10.1016/j.jpowsour.2010.08.056

Wagner, N., Eneli, H., Ballauff, M., Friedrich, K.A., 2016. Correlation of capacity fading processes and electrochemical impedance spectra in lithium / sulfur cells. J. Power Sources 323, 107-114. doi:10.1016/j.jpowsour.2016.05.032

Wild, M., Neill, L.O., Zhang, T., Purkayastha, R., Minton, G., Marinescu, M., Offer, G.J., 2015. Lithium sulfur batteries, a mechanistic review. Energy Environ. Sci. 8, 3477-3494. doi:10.1039/C5EE01388G

Xiong, S., Xie, K., Diao, Y., Hong, X., 2014. Characterization of the solid electrolyte interphase on lithium anode for preventing the shuttle mechanism in lithium-sulfur batteries. J. Power Sources 246, 840-845. doi:10.1016/j.jpowsour.2013.08.041

Yan, J., Liu, X., Li, B., 2014. Recent progress in Li-rich layered oxides as cathode materials for Liion batteries. RSC Adv. 4, 63268-63284. doi:10.1039/C4RA12454E

Yong, J.Y., Ramachandaramurthy, V.K., Tan, K.M., Mithulananthan, N., 2015. A review on the state-of-the-art technologies of electric vehicle, its impacts and prospects. Renew. Sustain. Energy Rev. 49, 365-385. doi:10.1016/j.rser.2015.04.130 
Yousif, S.E.A., Fotouhi, A., Auger, D.J., Propp, K., 2018. Self-Discharge Effects in Lithium-Sulfur Equivalent Circuit Networks for State Estimation. J. Electrochem. Soc. 165, A6081-A6090. doi:10.1149/2.0121801jes

Zackrisson, M., Avellán, L., Orlenius, J., 2010. Life cycle assessment of lithium-ion batteries for plug-in hybrid electric vehicles - Critical issues. J. Clean. Prod. 18, 1519-1529. doi:10.1016/j.jclepro.2010.06.004

Zakeri, B., Syri, S., 2015. Electrical energy storage systems: A comparative life cycle cost analysis. Renew. Sustain. Energy Rev. 42, 569-596. doi:10.1016/j.rser.2014.10.011

Zhang, S.S., 2012. Role of LiNO 3 in rechargeable lithium/sulfur battery. Electrochim. Acta 70, 344-348. doi:10.1016/j.electacta.2012.03.081

Zhang, T., Marinescu, M., O'Neill, L., Wild, M., Offer, G., 2015. Modeling the voltage loss mechanisms in lithium-sulfur cells: the importance of electrolyte resistance and precipitation kinetics. Phys. Chem. Chem. Phys. 17, 22581-22586.

doi:10.1039/С5CP03566J 